JURNAL NOMINAL / VOLUME VI NOMOR 1 / TAHUN 2017

\title{
PERANCANGAN SISTEM INFORMASI AKUNTANSI PENERIMAAN KAS BERBASIS WEB PADA BATIK PRAMANCA
}

\author{
Ambar Puspa Arum \\ Prodi Akuntansi Universitas Negeri Yogyakarta \\ arum.sunarno@gmail.com \\ Mahendra Adhi Nugroho \\ Staf Pengajar Jurusan Pendidikan Akuntansi Universitas Negeri Yogyakarta
}

\begin{abstract}
Abstrak: Perancangan Sistem Informasi Akuntansi Penerimaan Kas Berbasis Web Pada Batik Pramanca. Penelitian ini bertujuan untuk : (1) Mengetahui sistem informasi akuntansi penerimaan kas yang digunakan oleh Batik Pamanca. (2) Merancang sistem informasi akuntansi penerimaan kas berbasis web yang dapat diimplementasikan dan sesuai dengan kebutuhan Batik Pramanca. Penelitian ini merupakan penelitian research and development dengan metode pengembangan Rapid Application Development (RAD) yang terdiri dari tiga fase yaitu requirements planning, RAD design workshop, dan implementation. Data diperoleh melalui studi kepustakaan dan wawancara. Hasil penelitian ini adalah informasi sistem informasi akuntansi penerimaan kas manual yang digunakan pada Batik Pramanca. Fungsi yang terkait dengan penerimaan kas diantaranya fungsi penjualan, fungsi persediaan, dan fungsi pencatatan. Batik Pramanca belum memiliki pengendalian internal dan pembagian tugas yang jelas. Dokumen yang digunakan berupa nota tunai dan faktur, sementara catatan yang dibuat adalah catatan penjualan tunai, piutang, dan persediaan. Namun pencatatan tidak dilakukan dengan rutin sehingga ketersediaan informasi mengenai catatan tersebut sangat terbatas dan tidak akurat. Berdasarkan pada data tersebut, dibuat perancangan sistem informasi akuntansi penerimaan kas berbasis web dengan metode RAD. Tahap bussiness modelling menghasilkan data yang diperlukan untuk perancangan sistem. Tahap data modelling menghasilkan tabel data dan keterkaitannya dalam bentuk ERD. Tahap process modelling menghasilkan diagram konteks, DFD, diagram proses, dan desain interface program. Tahap application generation menghasilkan perubahan disain kedalam bahasa pemrograman. Dan tahap testing and turnover menghasilkan proses prima yang siap diimplementasikan.
\end{abstract}

Kata kunci: Sistem Informasi Akuntansi, Penerimaan Kas, Web

Abstract: Web Based Cash Acceptance Accounting Information System Design In Batik Pramanca. This research aims to: (1) know the cash acceptance accounting information system used by Batik Pramanca. (2) Design web based cash acceptance accounting information system which can be implemented and fit the needs of Batik Pramanca This research is a research and development research using Rapid Application Development (RAD) method which includes three stage which is requirements planning, RAD design workshop, and implementation. Data collected using literary studies survey and interview. The results of this research are information regarding cash acceptance accounting information system in Batik Pramanca which is manual based system. Some functions related to cash acceptance are sale function, supply function, and register function. Batik Pramanca have not got an internal control and clear job desk. Documents used in the business process are cash notes and invoices, and notes made are debit sale notes, credit, and supply. But registration activities are not routinely done so information available is not accurate. Based on the data this research produces a design of web based cash acceptance accounting information system using RAD methods. Bussines modelling stage generate the data needed for system design. Data modelling stage generate the data table and their correlation in ERD form. Process modelling stage generate the contextual diagram, DFD, process diagram, and design interface program. application generation stage generate the changes in design toward coding. And testing and turnover stage generate the prime process that is ready to be implemented.

Keywords: Accounting system information, Cash acceptance, Web 


\section{JURNAL NOMINAL / VOLUME VI NOMOR 1 / TAHUN 2017}

\section{PENDAHULUAN}

Perkembangan ilmu pengetahuan dan teknologi informasi yang pesat telah menjadi salah satu faktor pendorong dan memiliki peranan yang sangat penting dalam perkembangan perekonomian dunia. Keberadaan teknologi yang semakin canggih memungkinkan pengguna untuk melakukan pemanfaatan teknologi tepat guna. Salah satunya dengan membangun sistem informasi akuntansi.

Sistem informasi akuntansi merupakan suatu aplikasi sistem komputer yang digunakan untuk mengolah data akuntansi. Sistem informasi akuntansi memiliki peranan yang penting bagi perusahaan, karena sistem informasi akuntansi bersama dengan sistem informasi yang lain menyediakan informasi yang dibutuhkan oleh pihak manajemen sebagai dasar pengambilan keputusan. Sistem informasi akuntansi tidah sekedar berfungsi untuk pengolah atau pemroses data, tetapi juga menjalankan fungsi pengumpulan data, pemrosesan atau pengolahan data, manajemen data, pengendalian dan pengamanan data, dan fungsi penyedia informasi. Seiring dengan pertumbuhan pasar dan perkembangan teknologi, keberadaan sistem informasi akuntansi yang memadai semakin dibutuhkan oleh perusahaan. Baik unit usaha besar maupun unit usaha medium. Karena dengan adanya sistem informasi akuntansi yang memadai, pihak manajemen dimungkinkan untuk mengambil keputusan berdasarkan pada informasi yang lebih cepat dan akurat.

Dalam kegiatan bisnis, setidaknya terdapat lima aplikasi sistem informasi akuntansi yang saling terkait yaitu siklus penerimaan kas atau pendapatam, siklus pengeluaran, siklus produksi, siklus penggajian, dan siklus pelaporan. Aplikasi sistem informasi akuntansi yang saling terkait ini disebut dengan Enterprise Resource Planning (ERP). ERP merupakan sebuah konsep untuk merencanakan dan mengelola sumber daya perusahaan yang meliputi dana, sumber daya manusia, mesin, waktu, material dan kapasitas yang berpengaruh untuk manajemen dalam berbagai tingkatan dan kegiatan operasional perusahaan. Karena ERP merupakan kesatuan dari lima aplikasi sistem informasi akuntansi, maka pembuatan ERP dapat dilakukan secara bertahap. Dengan kata lain, pembangunan aplikasi sistem dilakukan satu per satu, baru kemudian digabungkan.

Beberapa sistem terkait yang membangun ERP diantaranya adalah sistem penerimaan kas. Kegiatan penerimaan kas adalah suatu kegiatan penerimaan/pemasukan/penambahan kas perusahaan/organisasi karena suatu transaksi. Penerimaan kas dapat berasal dari berbagai sumber diantaranya transaksi penjualan baik tunai maupun kredit, 


\section{JURNAL NOMINAL / VOLUME VI NOMOR 1 / TAHUN 2017}

penjualan aset, penerimaan pinjaman dan lain sebagainya. Kas yang diterima oleh perusahaan pun tidak harus selalu berupa uang tunai. Melainkan dapat berupa cek atau surat berharga yang dapat uangkan. Kegiatan penerimaan kas tidak harus dilakukan secara langsung. Karena sudah banyak pihak dan cara alternatif yang dapat digunakan dalam kegiatan penerimaan kas. Kegiatan penerimaan kas merupakan kegiatan yang penting dalam perusahaan. Karena dalam kegiatan ini rawan terjadi fraud misalnya kelalaian pencatatan dan jumlah yang tidak sesuai. Oleh karena itu dibutuhkan sebuah sistem penerimaan kas yang dapat meminimalisir kesalahan dalam kegiatan tersebut.

Dewasa ini, keberadaan jaringan internet yang kian memadai telah memberi pengaruh signifikan pada berbagai aspek dalam masyarakat. Banyak kemudahan yang ditawarkan oleh layanan internet, mulai dari kemudahan memperoleh informasi hingga bertransaksi. Dan dengan adanya dukungan jaringan internet, sistem informasi akuntansi dapat dikembangkan kedalam basis web. Pengembangan sistem informasi akuntansi kedalam basis web akan memberikan banyak keuntungan bagi perusahaan atau organisasi yang menggunakan sistem tersebut.

Batik Pramanca merupakan salah satu unit usaha manufaktur yang terletak di Gamping, Sleman, Daerah Istemewa
Yogyakarta. Produk yang diproduksi dan dipasarkan oleh Batik Pramanca merupakan produk-produk konveksi dengan bahan kain batik. Banyaknya unit usaha dengan produk serupa menjadi salah satu faktor pendorong bagi Batik Pramanca untuk melakukan inovasi pemasaran produk, mulai dari meningkatkan kualitas produk, menambah varian produk, hingga memperluas jangkauan pemasaran produk.

Keberadaan unit usaha Batik Pramanca yang baru memiliki satu gerai dengan sistem penjualan manual tentu tidak memungkinkan unit usaha ini untuk memperluas area pemasaran dan menjangkau semua wilayah. Belum tersedianya sistem informasi yang mempermudah pelanggan dalam melakukan transaksi tanpa harus datang kegerai dan sulitnya memperoleh informasi mengenai produk Batik Pramanca menjadi penyebab omset penjualan Batik Pramanca sulit meningkat. Karena itu, belum lama ini Batik Pramanca mulai melakukan penjualan secara online melalui beberapa jejaring sosial. Dengan begitu area pemasaran produk dapat diperluas. Sekaligus memudahkan calon konsumen untuk melihat sampel dan memperoleh informasi mengenai produk, melakukan pemesanan, dan melakukan pembayaran tanpa harus datang ke gerai Batik Pramanca yang terletak di Gamping. 
Dalam melakukan penjualan terutama secara online, respon yang cepat menjadi salah satu faktor penentu kepuasan konsumen. Namun tuntutan respon cepat oleh pelanggan sering kali menyebabkan admin kesulitan untuk melakukan rekap data penjualan. Sehingga pencatatan transaksi penerimaan kas dari penjualan online tidak dapat dilakukan dengan cepat dan akurat. Hal tersebut mengakibatkan kebutuhan informasi mengenai penerimaan kas Batik Pramanca tidak dapat diperoleh dengan optimal. Karena untuk mendapatkan laporan penerimaan kas, owner harus menyusun laporan penjualan manual dan penjualan online. Sementara itu, laporan penjualan online itu sendiri masih harus dicek ulang untuk memastikan bahwa pencatatan dilakukan dengan tepat. Oleh karena itu, sistem informasi akuntansi penerimaan kas manual yang digunakan oleh Batik Pramanca dapat dikatakan rumit dan memiliki probabilitas kesalahan yang tinggi, misalnya terjadi pencatatan ganda pada satu transaksi, atau kesalahan pencatatan nominal. Selain itu, sistem informasi akuntansi penerimaan kas manual memiliki tingkat keamanan yang rendah karena bukti-bukti transaksi dapat rusak atau hilang tanpa disengaja, dan belum tentu terdapat file bukti transaksi cadangan. Sehingga laporan penjualan/transaksi tidak akurat. Batik Pramanca belum memiliki sistem informasi akuntansi penerimaan kas yang memadai, untuk itu sebuah sistem informasi akuntansi penerimaan kas perlu dirancang dan dibangun untuk Batik Pramanca. Karena Batik Pramanca sudah mulai melakukan bisnis secara online, sistem informasi akuntansi penerimaan kas basis web dirasa cocok untuk unit usaha ini. Pembuatan sistem informasi akuntansi penerimaan kas diharapkan dapat mempermudah kegiatan bisnis pada unit usaha ini, meningkatkan akurasi informasi yang dibutuhkan oleh owner sebagai dasar pengambilan keputusan.

\section{METODE PENELITIAN}

\section{Jenis Penelitian}

Penelitian ini menggunakan pendekatan kualitatif dan merupakan jenis penelitian research and development.

\section{Tempat dan Waktu Penelitian}

Penelitian ini dilakukan pada bulan Maret-Mei 2016 di Batik Pramanca, Gamping Lor No. 14, RT. 02, RW.14, Ambarketawang, Gamping, Daerah Istimewa Yogyakarta.

\section{Target/Subjek Penelitian}

Target penelitian ini adalah sistem informasi akuntansi penerimaan kas pada Batik Peramanca.

\section{Teknik Pengumpulan Data}

Teknik pengumpulan data yang digunakan pada penelitian ini adalah studi kepustakaan dan wawancara. 


\section{Instrumen Penelitian}

Instrumen yang digunakan dalam penelitian ini berupa lembar wawancara beserta daftar pertanyaan, catatan dan formulir, pedoman observasi dan lembar hasil observasi. Wawancara akan dilakukan secara langsung dengan Bapak Hastha Pramanca sebagai narasumber.

\section{Prosedur}

Dalam penelitian ini, prosedur yang dilakukan merupakan tahapan perancangan sistem dengan metode Rapid Application Development. Tahap pertama yang dilakukan adalah membuat bussiness modelling. Dalam tahap ini akan diperoleh data-data mengenai sistem informasi akuntansi yang diterapkan pada Batik Pramanca. Tahap selanjutnya adalah data modelling, pada tahap ini dijelaskan data yang dibutuhkan dalam proyek. Baik jenis atribut maupun keterkaitan antar tabel datanya. Tahap ketiga adalah process modelling, dalam tahap ini data-data yang sudah disusun dalam data modelling ditransformasi untuk mendapat arus data yang diperlukan dalam proses bisnis. Dalam tahap ini dibuat DFD, diagram proses, hingga desain interface. Kemudian dilanjutkan dengan application generation, yaitu merubah desain kedalam bahasa pemrograman. Tahap terakhir adalah testing and turnover. Setelah program dibuat, dilakukan pengujian dan penyesuaian-penyesuaian yang dibutuhkan.
Data, Instrumen, dan Teknik Pengumpulan

a) Data

Data yang digunakan dalam penelitian ini merupakan data primer. Data dikumpulkan melalui proses wawancara dengan narasumber. Instrumen yang digunakan merupakan draft pertanyaan wawancara dan catatan guna mencatat hasil wawancara.

b) Teknik Analisis Data

1) Bussiness Modelling

Tahap ini untuk mencari aliran informasi yang dapat menjawab pertanyaan yang berkaitan dengan kebutuhan data dalam proses bisnis, informasi yang dimunculkan dan untuk apa informasi digunakan, kemudian penanggung jawab atas proses untuk menciptakan informasi tersebut.

\section{2) Data Modelling}

Tahap ini dilakukan dengan membuat permodelan database. Permodelan database dilakukan dengan membual permodelan data menggunakan ERD (Entity Relationshp Diagram) yang menunjukkan pembuatan informasi, penyimpanan, dan penggunaan informasi dalam sistem bisnis. Setelah memperoleh sampel data yang diperlukan, peneliti akan menentukan tabel-tabel yang perlu dibuat. Setelah ditentukan tabel apa saja yang dibutuhkan, kemudian dibuat field name dari tiap tabel sehingga dapat 
digunakan sebagai dasar pembuatan database. Setelah tabel dasar pembuatan database selesai dibuat, kemudian dilanjutkan dengan pembuatan query untuk menentukan keterkaitan dari tabeltabel permodelan tersebut. Dari desain file dan database akan dibuat tabel-tabel berikut:

Tabel 1. Daftar Tabel dan Fungsi

\begin{tabular}{|c|c|}
\hline $\begin{array}{l}\text { Tabel } \\
\text { Pelanggan }\end{array}$ & $\begin{array}{l}\text { Berfungsi } \\
\text { menyimpan data } \\
\text { registrasi account } \\
\text { pelanggan di web. } \\
\text { Tabel terdiri dari ID } \\
\text { customer, nama, e- } \\
\text { mail, alamat, dan } \\
\text { nomor telepon. }\end{array}$ \\
\hline $\begin{array}{l}\text { Tabel } \\
\text { Administrator }\end{array}$ & $\begin{array}{l}\text { Menyimpan data } \\
\text { karyawan seperti ID } \\
\text { admin, nama, e-mail, } \\
\text { alamat, dan nomor } \\
\text { telepon. }\end{array}$ \\
\hline Tabel Barang & $\begin{array}{l}\text { Menyimpan informasi } \\
\text { mengenai setiap item } \\
\text { yang terdapat di web } \\
\text { meliputi ID barang, } \\
\text { nama, harga, dan stok } \\
\text { barang. }\end{array}$ \\
\hline Tabel Beban & $\begin{array}{l}\text { Menyimpan daftar } \\
\text { harga pengiriman ke } \\
\text { kota tujuan } \\
\text { pengiriman. Tabel ini } \\
\text { berisi ID ekspedisi, ID } \\
\text { pesanan, berat barang, } \\
\text { dan biaya pengiriman. }\end{array}$ \\
\hline $\begin{array}{l}\text { Tabel } \\
\text { Pesanan }\end{array}$ & $\begin{array}{l}\text { Menyimpan data } \\
\text { barang yang dipesan } \\
\text { oleh pelanggan pada } \\
\text { tiap transaksi. Tabel ini } \\
\text { memberi informasi } \\
\text { tentang id pesan, id } \\
\text { customer, ID admin, } \\
\text { total pembayaran, dan } \\
\text { tanggal pesanan. }\end{array}$ \\
\hline
\end{tabular}

\begin{tabular}{ll}
\hline Tabel & Tabel ini merupakan \\
Pembayaran & tabel pembantu untuk \\
& transaksi penjualan \\
& kredit. Tabel ini berisi \\
& ID pembayaran, ID \\
& pesanan, uang muka, \\
& sisa pembayaran, \\
& tanggal jatuh tempo, \\
& status transaksi. \\
\hline Tabel Detail & Tabel detail pesanan \\
Pesanan & merupakan tabel yang \\
& menghubungkan tabel \\
& pesanan dengan tabel \\
& barang. Tabel detail \\
& barang berisi ID detail \\
& pesanan, ID pesanan, \\
& ID barang, jumlah \\
& barang, dan size yang \\
& diminta. \\
\hline Tabel Detail & Tabel detail \\
Pembayaran & pembayaran berisi ID \\
& detail pembayaran, ID \\
& pembayaran, update \\
& status transaksi, \\
& pembayaran, dan \\
& tanggal pembayaran. \\
& Tabel ini merupakan \\
& tabel lanjutan dari tabel \\
& pembayaran. \\
\hline &
\end{tabular}

\section{3) Process Modelling}

Tahap process modelling dilakukan dengan membuat permodelan proses melalui pembuatan diagram konteks sistem informasi penerimaan kas, Data Flow Diagram (DFD) sistem penerimaan kas tingkat 0 dan 1 yang mendeskripsikan proses arus informasi akuntansi penerimaan kas pada Batik Pramanca. Selanjutnya akan dilakukan desain interface input maupun output. 


\section{JURNAL NOMINAL / VOLUME VI NOMOR 1 / TAHUN 2017}

\section{4) Application Generation}

Tahap ini dilakukan untuk merubah disain kedalam bahasa pemrograman.

\section{5) Testing and Turnover}

Tahap ini dilakukan untuk menguji kesesuaian aplikasi dengan desain yang telah dibuat. Melakukan penyesuaian jika diperlukan. Dan mengajarkan cara penggunaan kepada user.

\section{HASIL PENELITIAN DAN PEMBAHASAN}

\section{Jenis Penerimaan}

Batik Pramanca memiliki tiga sumber penerimaan kas yaitu: (1)Penerimaan kas dari penjualan tunai. Penjualan tunai dilakukan secara on line dan off line. Penjualan tunai yang dilakukan secara on line mewajibkan pembeli untuk mentransfer sejumlah uang pada rekening Batik Pramanca sebelum barang pesanan dikirim. Dan biaya yang diperlukan atas pengiriman barang dibebankan kepada pembeli. Penjualan tunai yang dilakukan secara offline pada Batik Pramanca adalah penjualan tunai yang dilakukan langsung di outlet Batik Pramanca. (2) Penerimaan kas dari pembayaran uang muka atas penjualan kredit. Penjualan kredit baik online maupun offline mewajibkan konsumen untuk membayarkan 50\% dari total harga yang harus dibayarkan sebagai uang muka. Uang muka ini dibayarkan saat melakukan pemesanan. (3) Penerimaan kas dari piutang atas penjualan kredit.
Penjualan kredit baik online maupun off line pada akhirnya akan menimbulkan akun piutang sejumlah 50\% sisa dari uang muka yang telah diserahkan saat pemesanan. Piutang ini harus dilunasi oleh pelanggan pada saat barang telah siap diserahkan atau dikirim.

\section{Dokumen dan Catatan}

Dokumen yang digunakan dalam proses penerimaan kas Batik Pramanca adalah nota dan faktur. Sementara catatan yang digunakan adalah catatan penjualan, piutang, dan persediaan. Namun hingga saat ini kegiatan pencatatan tidak dilakukan dengan baik. Back up bukti transaksi dan catatan tidak dikelola dangan baik, sehingga hampir seluruh catatan yang digunakan sudah dinyatakan hilang oleh pihak manajemen. Selain mempersulit proses perancangan sistem, ketiadaan dokumen dan catatan tersebut mengindikasikan tidak adanya manajemen pengelolaan data yang baik pada Batik Pramanca. Fungsi dan prosedur pencatatan juga tidak berjalan dengan baik. Disamping berakibat hilangnya data-data berupa catatan dan dokumen pendukung kegiatan bisnis tersebut, pihak manajemen tidak dapat memperoleh informasi konkret yang akurat dan sesuai dengan kebutuhan. Sehingga pihak manajemen mengalami kesulitan untuk meninjau perkembangan bisnis maupun merencanakan tindakan 


\section{JURNAL NOMINAL / VOLUME VI NOMOR 1 / TAHUN 2017}

yang tepat untuk kegiatan bisnis kedepannya.

\section{Fungsi Terkait}

Fungsi-fungsi yang terkait dengan fungsi sistem penerimaan kas pada Batik Pramanca antara lain fungsi penjualan, fungsi persediaan (gudang), dan fungsi pencatatan. Pada fungsi penjualan dilakukan proses penerimaan pesanan dari pelanggan. Pada fungsi persediaan dilakukan update pencatatan persediaan dan jenis barang, fungsi persediaan ini juga merangkap sebagai fungsi pengiriman barang. Pada fungsi pencatatan dilakukan prosedur pencatatan transaksi atas penjualan dan penerimaan kas. Secara garis besar fungsi-fungsi yang terkait sudah cukup mampu memberi support pada sistem penerimaan kas. Namun pembagian tugas pada fungsi-fungsi tersebut kurang spesifik dak belum semua fungsi yang terkail dijalankan dengan optimal. Akibatnya terjadi kerancuan dalam tanggungjawab melakukan tugas dan perbedaan skala tanggungjawab yang diberikan, khususnya pada fungsi persediaan. Dalam jangka panjang, sebaiknya dilakukan pembagian tugas yang lebih spesifik. Agar setiap fungsi dapat berproses secara optimal.

\section{Prosedur}

Prosedur yang dilakukan dalam kegiatan penerimaan Batik Pramanca antara lain perosedur penjualan, dalam prosedur ini pesanan dari pelanggan diterima dan dicatat. Selanjutnya adalah prosedur penerimaan kas, pada prosedur ini pembayaran atas barang baik secara keseluruhan, uang muka, maupun pelunasan diterima dan faktur atau nota diotorisasi. Setelah itu prosedur persediaan (gudang) pada prosedur ini barang yang dipesan disiapkan. Pada penjualan kredit, barang akan dikirim atau diserahkan pada pelanggan setelah pelunasan diterima dan prosedur penerimaan memberikan nota bukti pelunasan. Prosedur terakhir yang dilakukan adalah prosedur pencatatan. Pada prosedur ini transaksi penjualan dan penerimaan kas akan di catat ulang sebagai input laporan penjualan dan penerimaan kas. Prosedur yang dilakukan dalam setiap fungsi sudah sesuai, tergolong sederhana dan mudah untuk dijalankan. Namun pada realitanya, terdapat prosedur yang tidak dijalankan dengan baik, yaitu prosedur pencatatan. Mengingat peranan penting prosedur ini, idealnya prosedur ini dilakukan dengan baik untuk memperoleh hasil yang maksimal. Prosedur pencatatan yang tidak dilakukan dengan baik akan mengakibatkan hasil informasi yang diciptakan memiliki kualitas yang buruk. Karena informasi tersebut tidak akurat dan belum tentu dapat dipertanggungjawabkan. Penggunaan informasi berkualitas buruk dalam pengambilan keputusan dapat 


\section{JURNAL NOMINAL / VOLUME VI NOMOR 1 / TAHUN 2017}

berakibat fatal pada proses bisnis kedepannya. Dengan kata lain, kualitas informasi sangat mempengaruhi ketepatan keputusan yang diambil oleh pihak manajemen. Jika prosedur ini tidak dilakukan dengan baik, dalam jangka panjang akan mengakibatkan kerugian yang besar pada unit usaha tersebut. Sehingga sangat baik untuk memperbaiki jalannya prosedur pencatatan sesegera mungkin.

\section{Alur Sistem Informasi Akuntansi Penerimaan Kas yang Diterapkan}

Alur sistem akuntansi penerimaan kas manual yang diterapkan pada Batik Pramanca berawal dari kegiatan penerimaan pesanan pada fungsi pembayaran, kemudian fungsi penerimaan kas akan menerima pembayaran atas pesanan tersebut. Pada pesanan tunai, barang akan langsung diambilkan dari gudang dan diserahkan pada setelah transaksi selesai. Pada penjualan kredit yang biasanya terjadi pada penjualan dengan skala besar sehingga butuh beberapa hari untuk menyelesaikan pesanan, fungsi penerimaan kas akan menerima $50 \%$ dari total nilai penjualan sebagai uang muka, sisanya akan diterima setelah barang siap dikirim dari gudang. Setelah transaksi dilakukan, nota dan faktur akan di back up dalam fungsi pencatatan. Jika dilakukan dengan maksimal, alur sistem manual tersebut akan dapat menghasilkan informasi penerimaan kas dengan kualitas prima. Namun karena tidak dilakukan dengan maksimal, alur sistem manual tersebut tidak dapat menghasilkan informasi akurat dan sesuai dengan kebutuhan. Dampak dari ketidaktersediaan informasi yang memadai tersebut, manajemen Batik Pramanca sulit untuk mengambil keputusan-keputusan dalam kegiatan bisnisnya.

\section{Informasi Terkait Sistem Informasi}

\section{Akuntansi Penerimaan Kas yang Dibutuhkan}

Informasi terkait dengan kegiatan penerimaan kas yang dibutuhkan oleh Batik Pramanca secara garis besar adalah laporan penjualan, laporan penerimaan kas, laporan piutang, dan laporan persediaan barang dagang. Berdasarkan garis bersar tersebut, kebutuhan akan informasi Batik Pramanca diperinci menjadi laporan penjualan keseluruhan, tunai, kredit, online, dan offline. Laporan penerimaan kas keseluruhan, online, dan offline. Laporan piutang, persediaan, dan history (riwayat $\log$ in). Jika ditinjau pada konten dokumen yang digunakan dalam kegiatan bisnisnya, seluruh informasi yang dibutuhkan oleh Batik Pramanca seharusnya dapat terpenuhi. Namun hingga saat ini, kebutuhan informasi belum terpenuhi karena kegiatan pencatatan dan pengelolaan dokumen bukti transaksi tidak dilakukan dengan baik. Oleh karena itu 
sistem informasi akuntansi penerimaan kas basis web dibuat terintegrasi agar dapat menghasilkan seluruh informasi yang dibutuhkan. Karena standar sistem informasi akuntansi penerimaan kas hanya menghasilkan laporan penerimaan kas saja.

\section{Penanggungjawab Penciptaan dan Penggunaan Informasi}

Tanggungjawab terciptanya informasi atas kegiatan penerimaan kas dan kegiatan operasional lainnya merupakan tanggungjawab owner, karena usaha ini dikelola langsung oleh owner. Dan seluruh hasil pengolahan data dalam sistem informasi akuntansi penerimaan kas akan digunakan juga oleh owner sebagai acuan dalam pengambilan keputusan. Selama manajemen Batik Pramanca belum mempekerjakan pegawai untuk mengelola kegiatan bisnisnya, maka tanggungjawab penciptaan informasi akan tetap dipegang oleh owner selaku pengelola. Namun jika dikemudian hari manajemen Batik Pramanca memutuskan untuk menggunakan pegawai untuk mengelola, maka tanggungjawab tersebut akan dilimpahkan kepada pegawai. Dalam proses pelimpahan tanggungjawab yang mungkin akan dilakukan, pelatihan pegawai hingga benar-benar siap sangat diperlukan. Mengingat pentingnya peranan informasi yang akan dihasilkan terhadap keputusan yang diambil pihak manajemen Batik Pramanca.

\section{Sistem Pengendalian Internal}

Batik Pramanca belum menerapkan sistem pengendalian internal apapun. Hal tersebut dikarenakan Batik Pramanca dikelola langsung oleh owner dengan dibantu oleh istrinya. Sehingga owner merasa pengendalian internal tidak diperlukan. Dalam setiap jenis usaha idealnya digunakan sebuah sistem pengendalian internal untuk melindungi asset, akurasi catatan dan informasi akuntansi, mendorong efisiendi, dan mendorong terlaksananya kebijakan yang telah ditetapkan pihak manajemen. Mengingat pentingnya peran sistem pengendalian internal dalam sebuah unit usaha, kedepannya Batik Pramanca perlu untuk segera menerapkan pengendalian internal. Terutama jika pihak manajemen Batik Pramanca sudah memutuskan untuk menambah karyawan.

\section{Perancangan Sistem Iformasi Akuntansi}

\section{Penerimaan Kas Basis Web}

Perancangan sistem informasi akuntansi penerimaan kas berbasis web yang sesuai dengan kebutuhan Batik Pramanca adalah desain sistem yang mampu menghasilkan output berupa informasi yang dibutuhkan dalam kegiatan operasional Batik Pramanca. 


\section{JURNAL NOMINAL / VOLUME VI NOMOR 1 / TAHUN 2017}

\section{a) Bussiness Modelling}

Pada tahap ini dihasilkan identifikasi kebutuhan data input yang dibutuhkan untuk menghasilkan informasi. Data input tersebut berupa: (1) data pelanggan (2) data admin (3) data barang. Sementara data output yang dibutuhkan dan diharapkan dapat diperoleh melalui input data tersebut berupa: (1) data pesanan (2) laporan penerimaan kas (3) laporan penjualan (4) laporan piutang (5) catatan beban (6) laporan persediaan. Pada Batik Pramanca, owner merupakan pengguna sekaligus penanggungjawab atas terciptanya informasi terkait kegiatan penerimaan kas.

\section{b) Data Modelling}

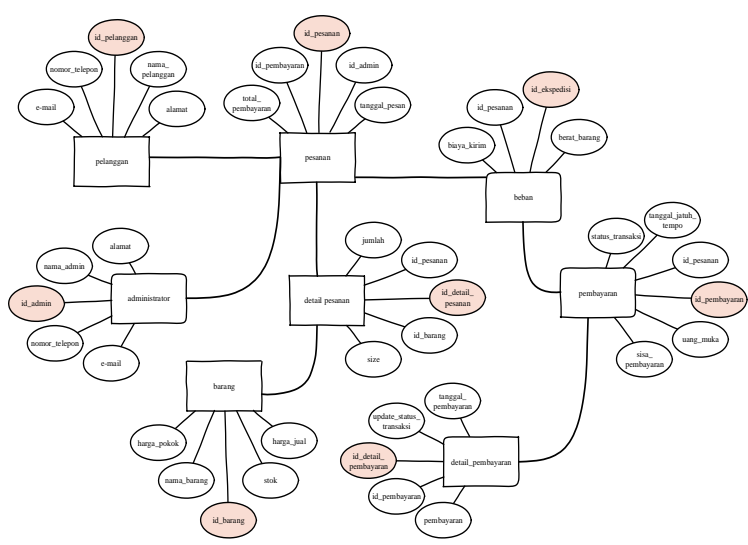

Gambar 1. Desain Database

Pada tahap ini dihasilkan ERD yang mengidentifikasi atribut data proyek dan hubungan atar objek data. Dalam perancangan sistem informasi akuntansi penerimaan kas berbasis web ini digunakan delapan tabel yaitu tabel pelanggan, tabel administrator, tabel pesanan, tabel barang, tabel detail pesanan, tabel pembayaran, tabel detail pembayaran, dan tabel beban. Tabel pelanggan adalah tabel yang berisi data pelanggan dengan atribut id pelanggan, nama, alamat, e-mail, dan nomor telepon. Hampir sama dengan tabel pelanggan, tabel administrator berisi data admin. Atribut yang digunakan pada tabel administrator adalah id administrator, nama, alamat, e-mail, dan nomor telepon. Tabel pesanan merupakan tabel yang berisi data pesanan dengan atribut id pesanan, id pelanggan, id administrator, total pembayaran, dan tanggal pesanan. Selanjutnya adalah tabel barang, tabel barang berisi data barang dengan atribut id barang, nama barang, harga barang, dan stok barang. Kemudian terdapat tabel detail pesanan. Tabel ini berfungsi untuk menghubungkan tabel pesanan dengan taabel barang. Tabel detail pesanan memiliki atribut id detail pesanan, id pesanan, id barang, jumlah barang, dan size yang diinginkan. Tabel selanjutnya adalah tabel pembayaran, pada tabel pembayaran terdapat atribut berupa id pembayaran, id pesanan, uang muka, sisa pembayaran, status transaksi, dan tanggal jatuh tempo. Tabel pembayaran dilanjutkan dengan tabel detail pembayaran, tabel ini berisi atribut berupa id detail pembayaran, id pembayaran, update status transaksi, tanggal 
pembayaran, dan pembayaran. Tabel terakhir yang digunakan adalah tabel beban dengan atribut id ekspedisi, id pesanan, berat barang, dan biaya pengiriman.

\section{c) Process Modelling}

Pada tahap ini dibuat diagram konteks, data flow diagram, dan diagram proses yang kemudian dibuat dalam tampilan desain antar muka.

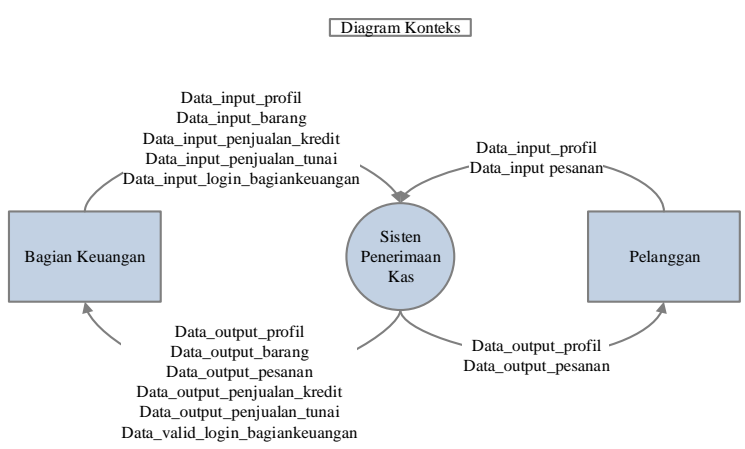

Gambar 2. Diagram Konteks

Diagram konteks yang dibuat merupakan diagram konsep dasar berisi jenis data input dan output.

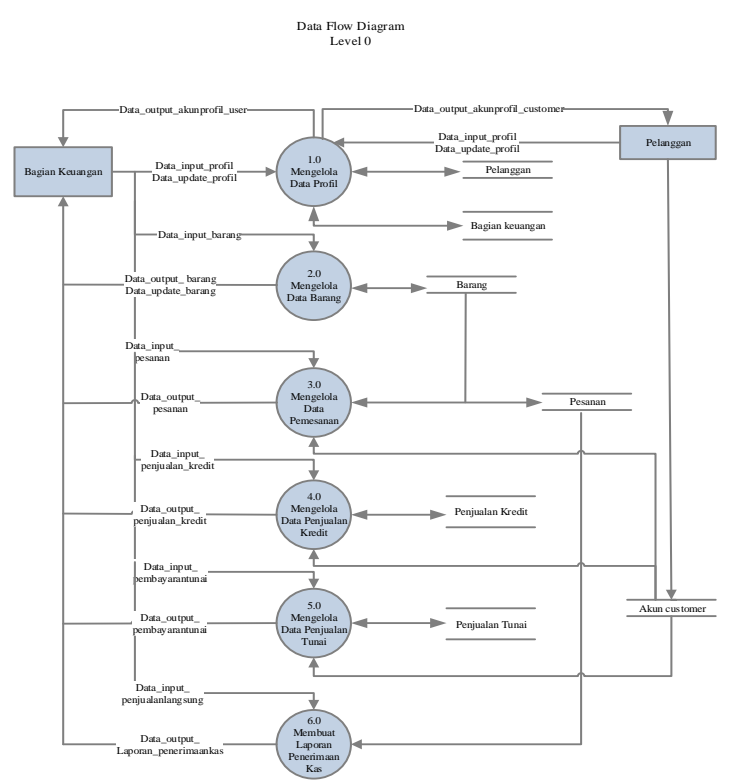

Gambar 3. DFD Level 0
Data flow diagram level 0 untuk menggambarkan alur data input dan output pada setiap prosedur dalam rancangan sistem informasi akuntansi penerimaan kas, sumber data input, dan akses data output. Dalam sistem ini, terdapat enam proses yang saling terkait. Proses-proses ini kemudian akan diperinci pada data flow diagram level 1.

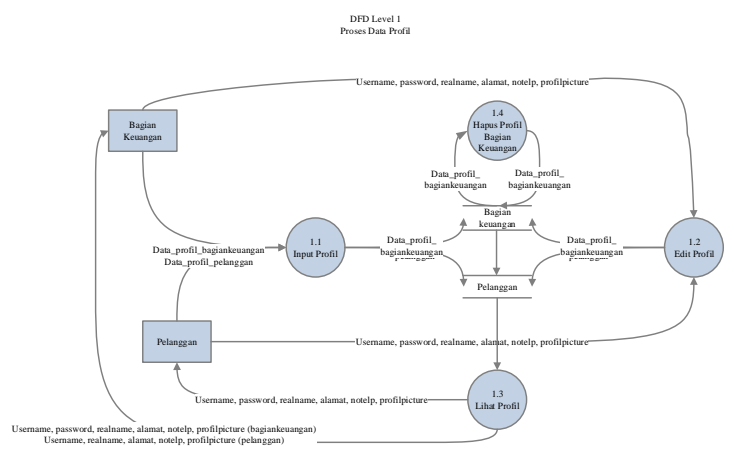

Gambar 3. DFD Tingkat 1 Data Profil

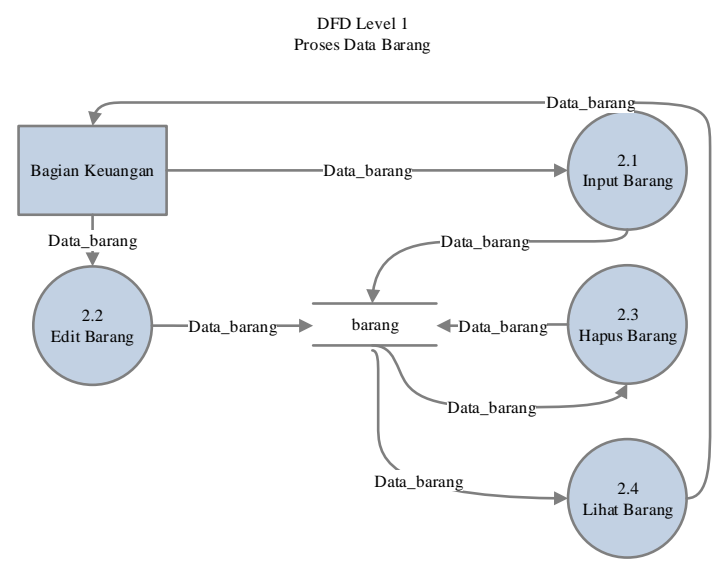

Gambar 4. DFD Tingkat 1 Data Barang 


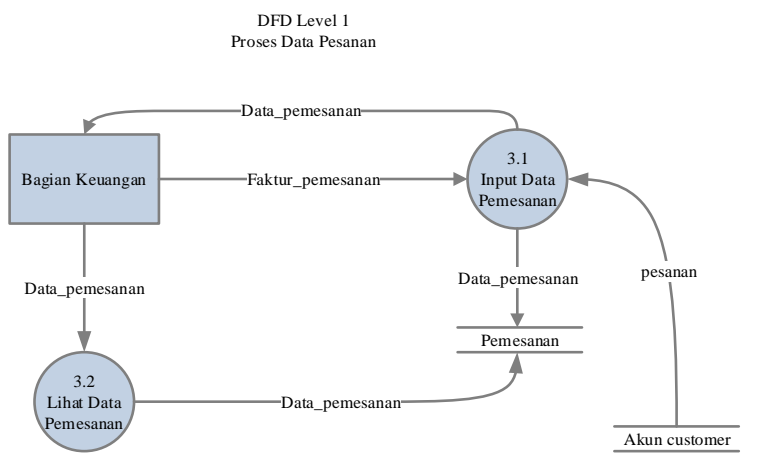

Gambar 5. DFD Tingkat 1 Data Pesanan

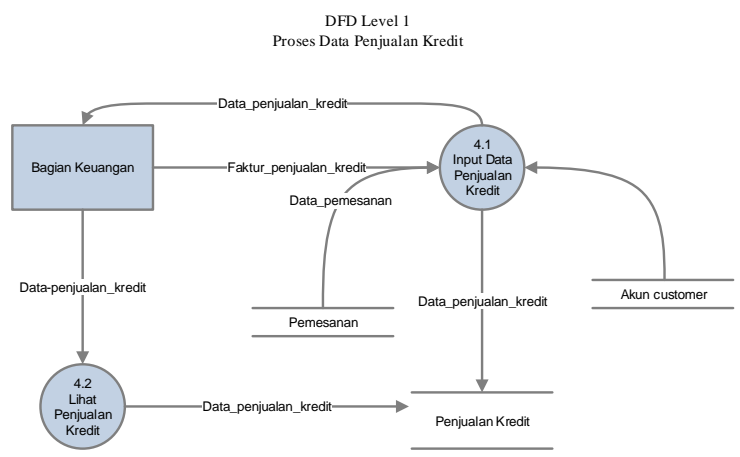

Gambar 6. DFD Tingkat 1 Penjualan Kredit

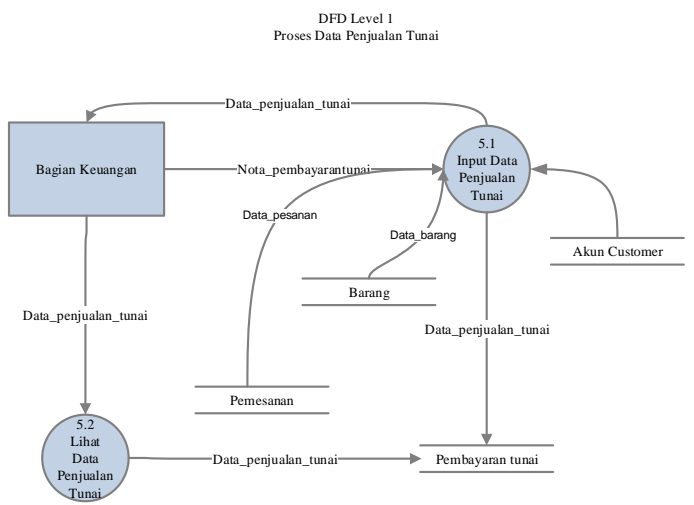

Gambar 7. DFD Tingkat 1 Penjualan

Tunai

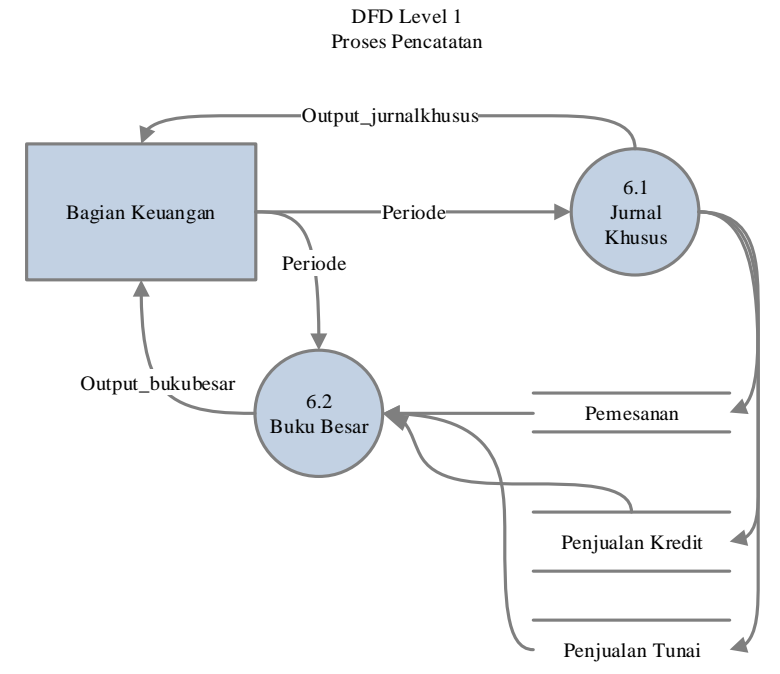

Gambar 8. DFD Tingkat 1 Proses Pencatatan

Pada DFD level 1. Proses-proses yang telah digambar pada diagram konteks dijabarkan dengan lebih terperinci, baik dari segi subproses maupun alur data dalam proses tersebut. Setelah DFD level 1 selesai dibuat, kemudian dilanjutkan dengan membuat diagram proses. 
Proses Log in dan Sing up Konsumen

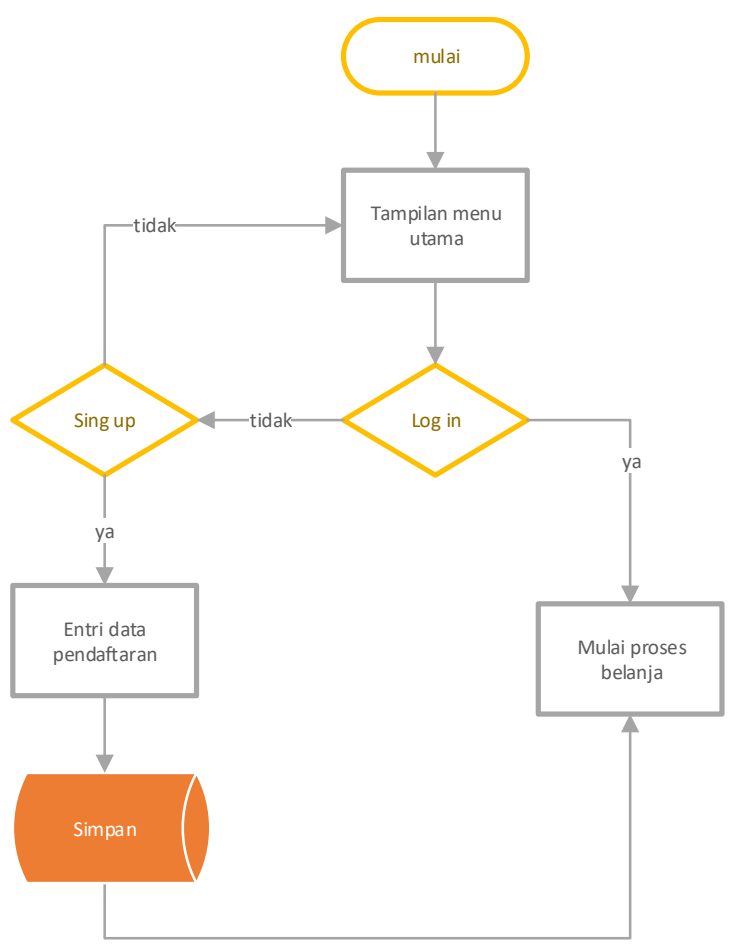

Gambar 9. Diagram Proses Log in dan Sign up customer

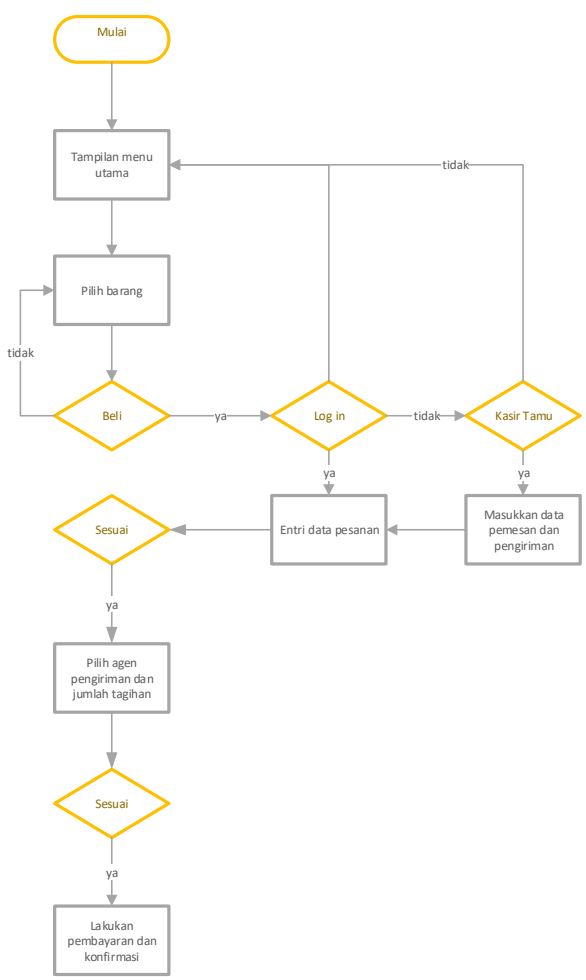

Gambar 10. Diagram Proses Beli
Proses Pembayaran

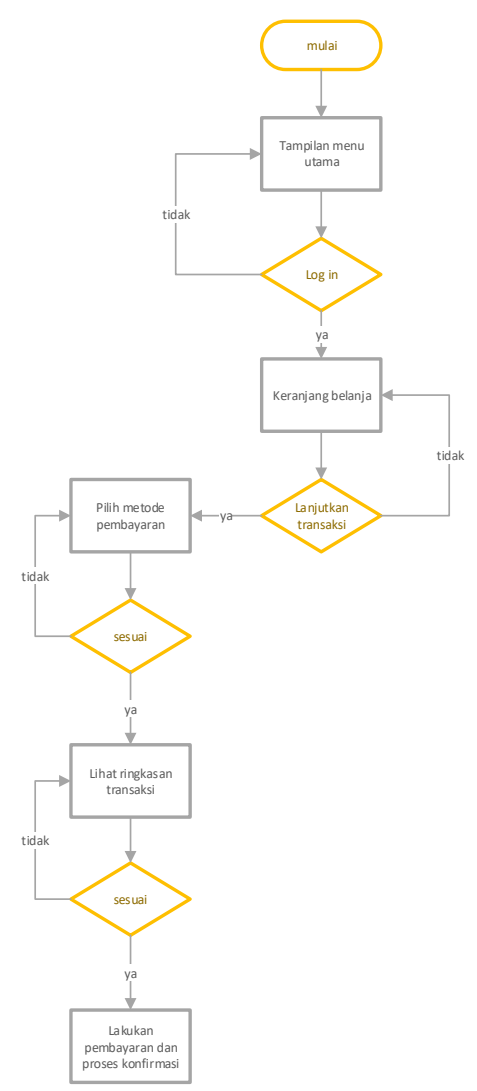

Gambar 12. Diagram Proses Pembayaran 
JURNAL NOMINAL / VOLUME VI NOMOR 1 / TAHUN 2017

Proses Konfirmasi

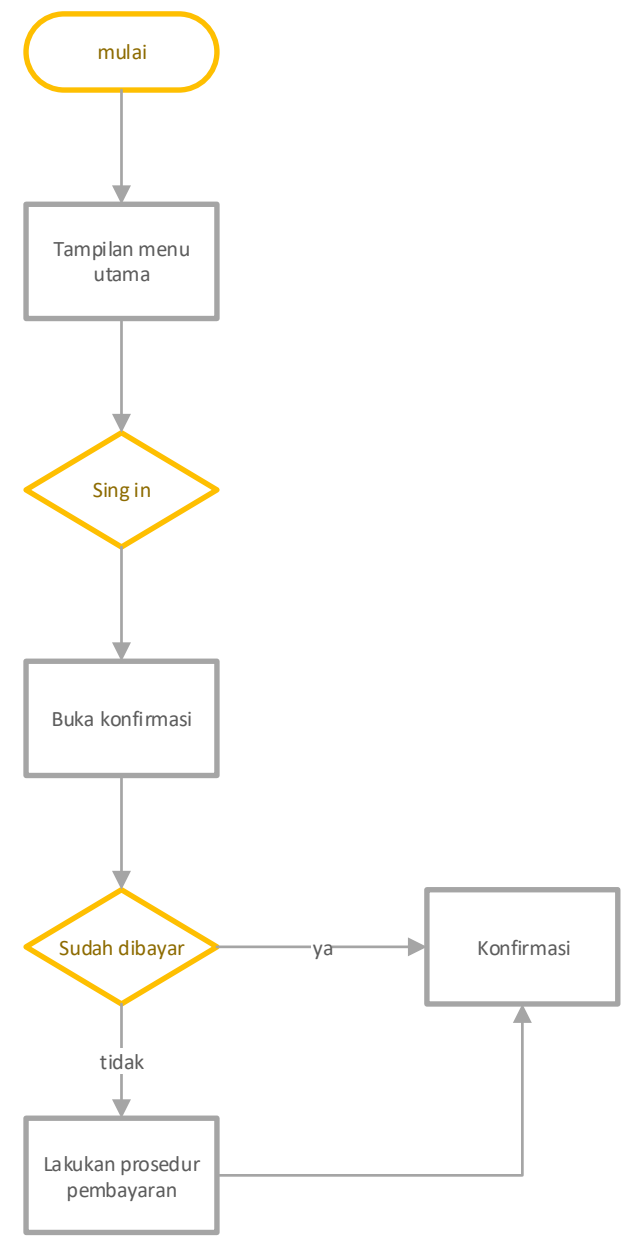

Gambar 12. Diagram Proses Konfirmasi

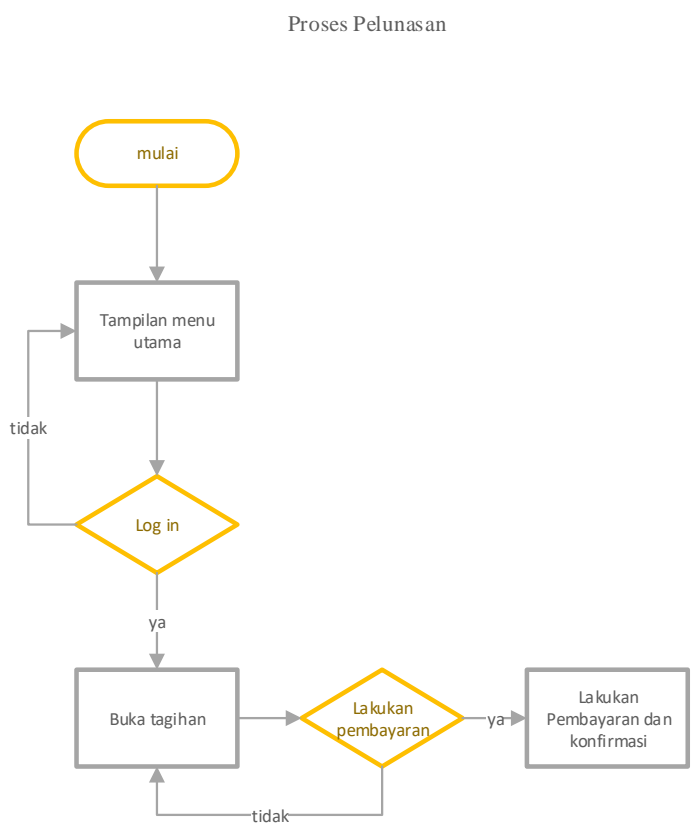

Gambar 13. Diagram Proses Pelunasan

Log in user

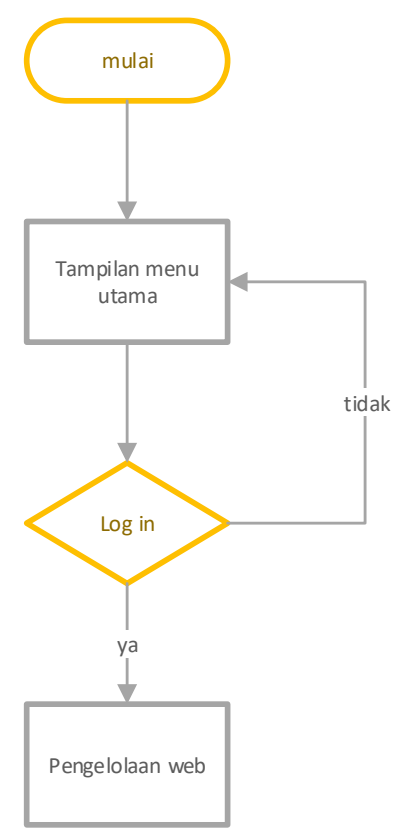

Gambar 14. Diagram Proses Log in user Tambah User

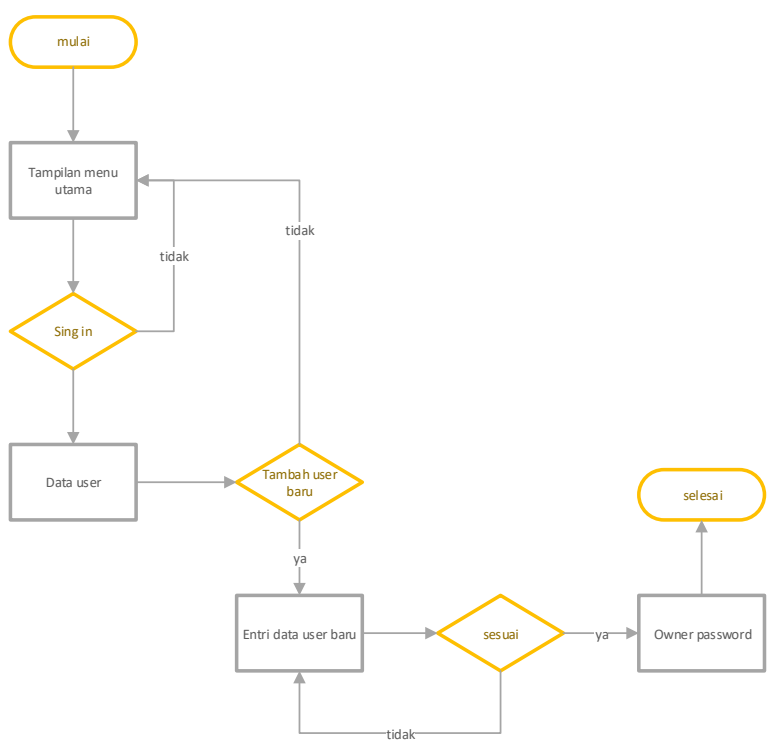

Gambar 15. Diagram Proses Tambah User 


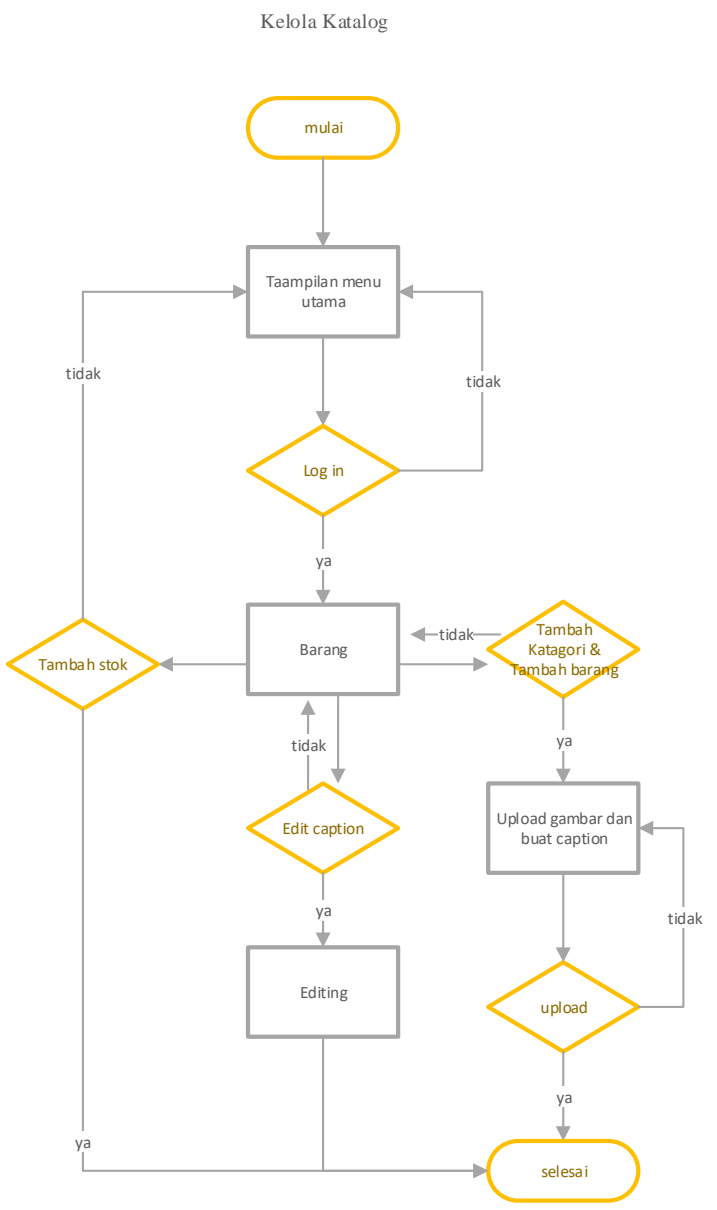

Gambar 16. Diagram Proses Kelola Katalog

Membuka Pesanan
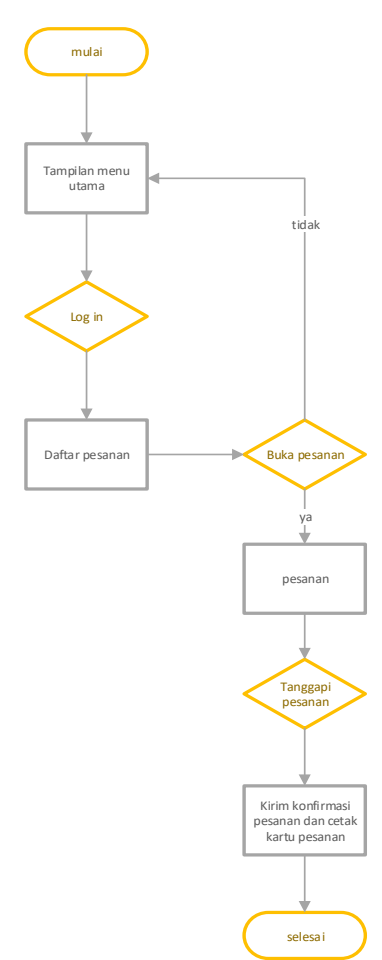

Gambar 17. Diagram Proses Membuka

Pesanan

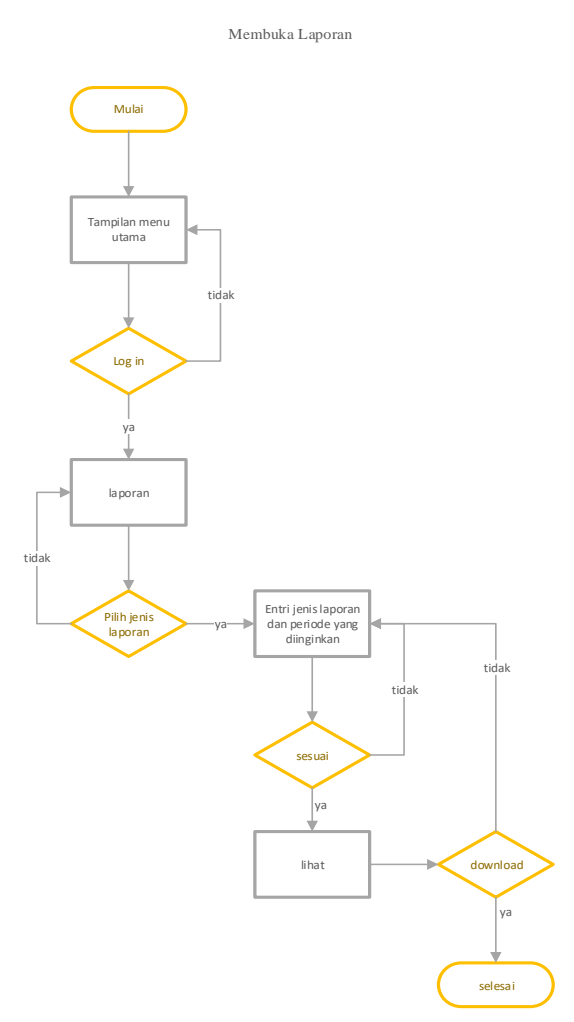

Gambar 18. Diagram Proses Membuka Laporan

Mengirim Tagihan

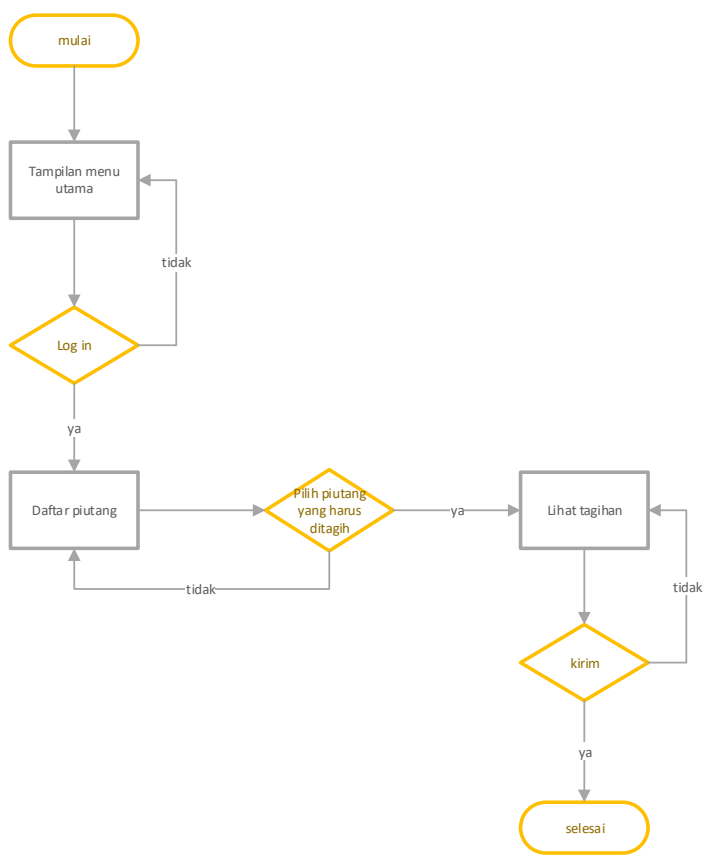


Gambar 19. Diagram Proses Mengirim

Tagihan

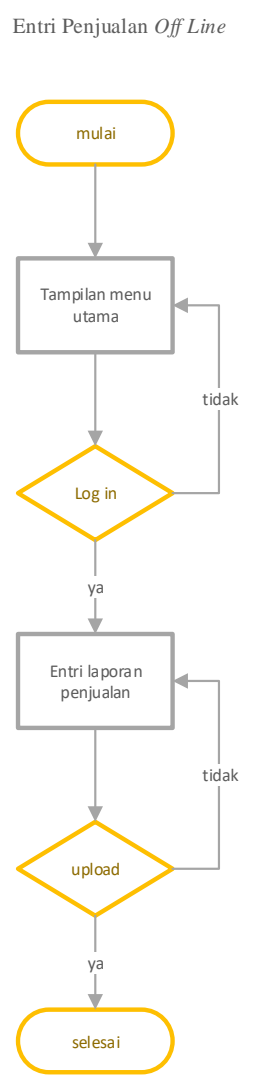

Gambar 20. Diagram Proses Entri

Penjualan Off Line

Diagram proses dibuat sesuai dengan kebutuhan pengguna akan sistem tersebut. Sehingga diagram proses dibuat dari sudut pandang customer dan admin. Setelah diagram proses selesai, perancangan dilanjutkan dengan membuat desain antar muka (interface).

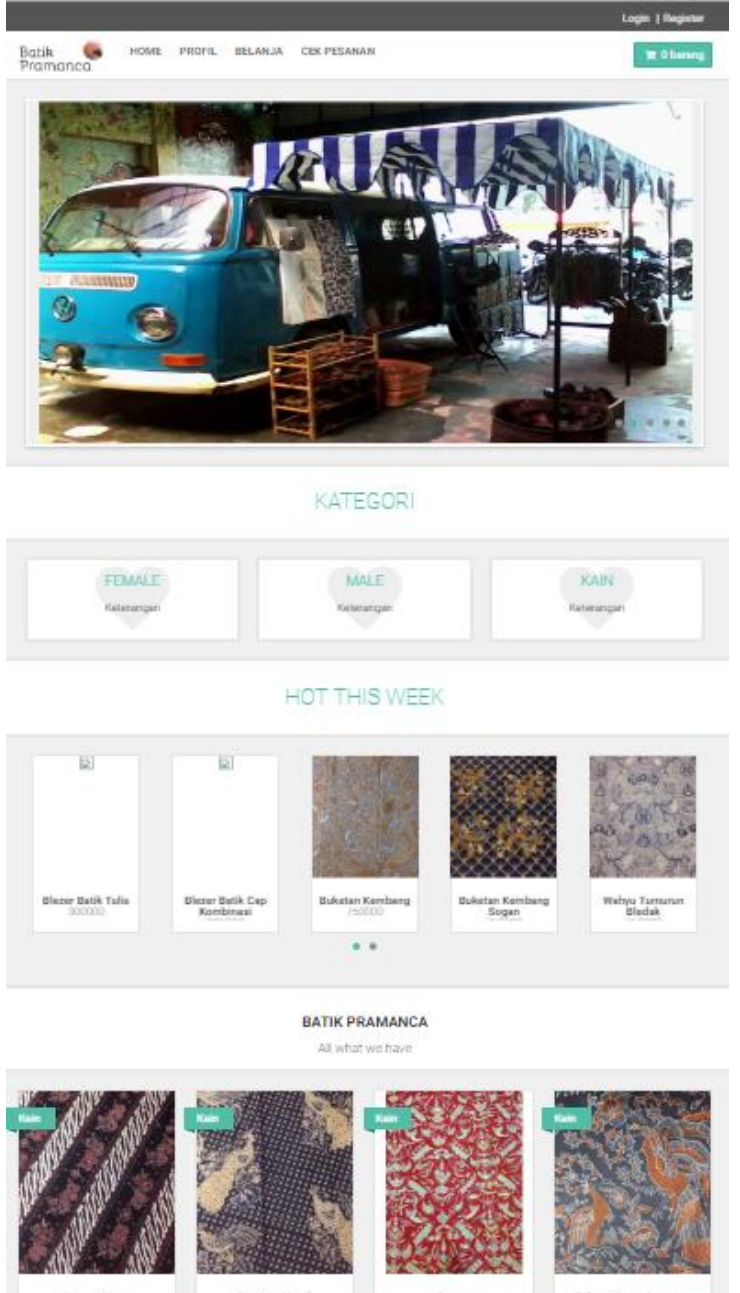

Gambar 21. Tampilan Menu Utama

Desain interface dibuat dalam dua layer sesuai dengan desain proses yang telah dibuat. Gambar diatas merupakan tampilan menu utama yang akan muncul sebelum melakukan login. Pada bagian tengah terdapat random slide tentang Batik Pramanca. Kemudian terdapat tiga katagori dari produk-produk Batik Pramanca. Setelah tampilan katagori, terdapat gambar-gambar produk yang baru di upload. Kemudian pada bagian bawah terdapat gambar-gambar produk batik pramanca. Untuk melakukan kegiatan 
belanja, pelanggan tidak diharuskan untuk menjadi member Batik Pramanca. Dengan kata lain, pelanggan tidak harus melakukan register jika belum memiliki akun belanja. Perbedaan kegiatan belanja melalui akun member dan tanpa akun member terdapat pada prosedur pemesanan barang. Pada pembelanjaan dengan akun member, pelanggan tidak perlu memasukkan informasi destinasi pengiriman barang. Sementara tanpa akun member, pelanggan harus mengisikan informasi destinasi pengiriman barang secara manual. Keuntungan lain yang didapat dengan memiliki akun member adalah kemudahan untuk melakukan kegiatan pemantauan dan konfirmasi pesanan.

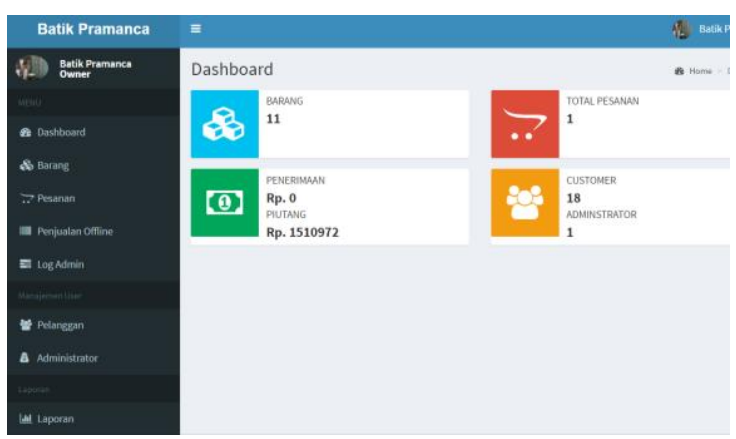

Gambar 22. Tampilan Utama Admin

Tampilan diatas merupakan tampilan yang akan muncul setelah melakukan login sebagai administrator. Pada tampilan ini terdapa menu bar berisi menu dashbor, barang, pesanan, penjualan offline, $\log$ admin, pelanggan, administrator, dan laporan. Pada tampilan dashbor terdapat informasi penting yang harus diketahui oleh admin yaitu jumlah item barang yang telah di upload. Jumlah item berbeda dengan jumlah stok barang, jumlah stok barang merupakan jumlah persediaan barang per item. Pada sebelah kiri terdapat jumlah pesanan baru yang masuk. Kemudian terdapat jumlah penerimaan dan piutang yang dimiliki. Yang terakhir adalah jumlah customer yang telah menjadi member dan administrator.

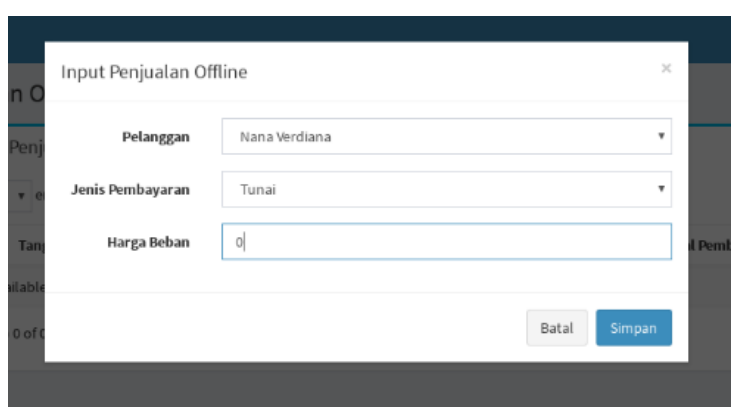

Gambar 23. Tampilan Input Penjualan Offline 1

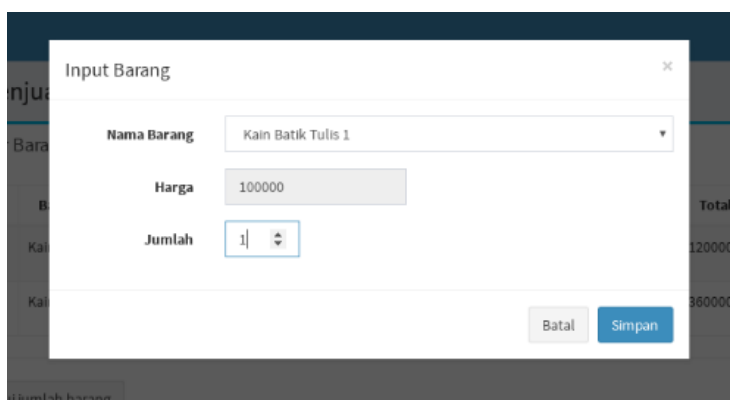

Gambar 24. Tampilan Input Penjualan Offline 2

Dua tampilan diatas merupakan form yang muncul untuk menginput laporan penjualan offline. Input laporan dilakukan dalam dua tahap. Tahap pertama, admin 
harus mengisikan form berisi nama pelanggan (opsional), jenis pembayaran, dan jumlah beban. Setelah selesai mengisi form pertama, selanjutnya harus dilakukan pengisian form input barang. Pada form ini admin hanya perlu memilih nama barang yang dibeli dan jumlah barang yang dibeli, sementara harga akan muncul secara otomatis.

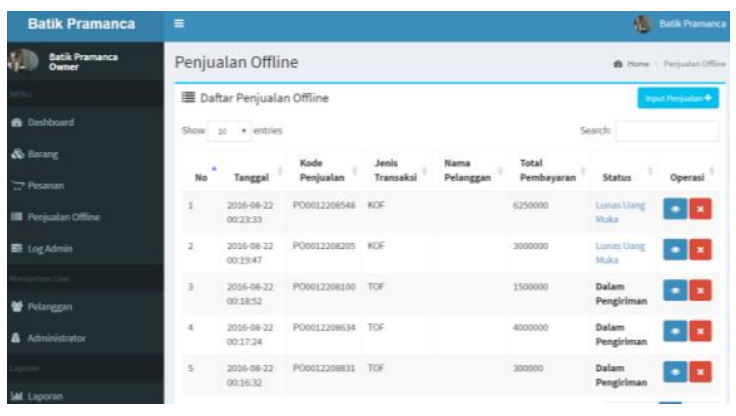

Gambar 25. Tampilan Penjualan Offline

Setelah melakukan input penjualan offline, maka tampilan penjualan offline menjadi seperti Gambar 25. Pada tampilan ini akan muncul tanggal input transaksi (auto), kode penjualan (auto), jenis transaksi, nama pelanggan (opsional), total pembayaran, dan status transaksi.

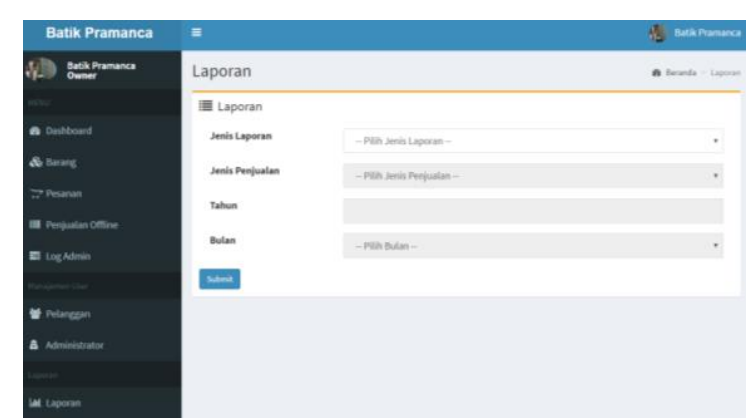

Gambar 26. Tampilan Awal Laporan.

Tampilan diatas merupakan tampilan awal yang muncul saat ingin mengakses laporan. Pada tampilan tersebut terdapat form yang berfungsi sebagai filter guna mengakses laporan yang diinginkan. Dalam menggunakan filter tersebut, admin dihimbau agar memasukkan data yang tepat agar dapat memunculkan laporan yang diinginkan.

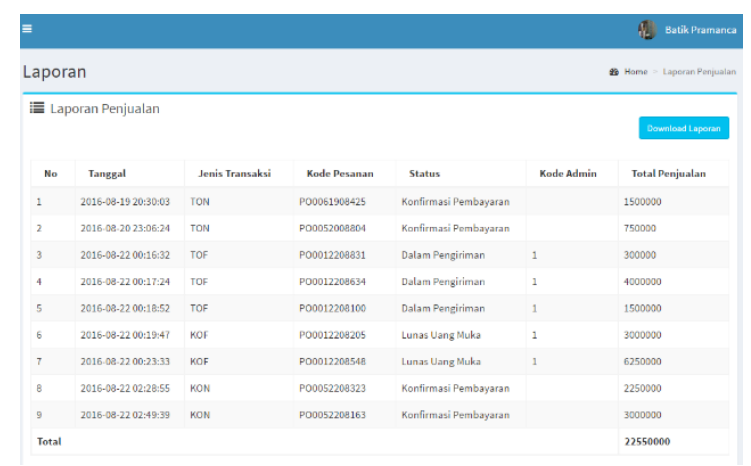

Gambar 27. Tampilan Laporan Penerimaan Kas

Gambar diatas merupakan salah satu tampilan lamporan yang dapat dimunculkan. Pada tampilan diatas diperlihatkan laporan penerimaan kas. Laporan penerimaan kas berisi tanggal transaksi, jenis transaksi kode pesanan, kode admin, jumlah penerimaan, dan total penerimaan pada bulan tersebut. Pada setiap laporan terdapat button download yang berfungsi untuk mendownload laporan agar dapat dibaca secara offline.

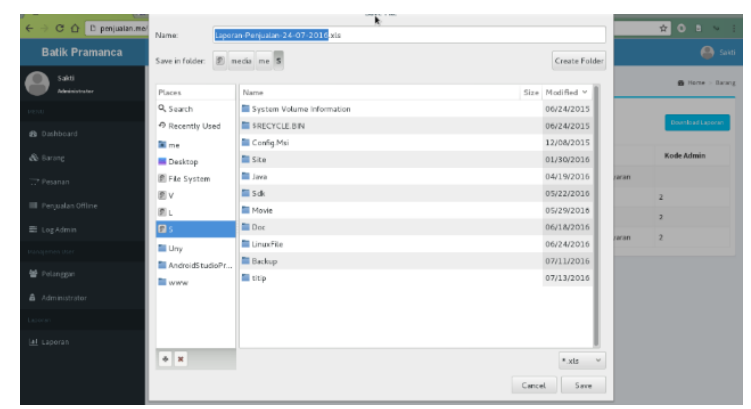


Gambar 28. Tampilan Download Laporan

Tampilan download laporan adalah tampilan yang muncul ketika button download pada laporan ditekan. Setelah tampilan ini muncul, pilih lokasi penyimpanan file yang diinginkan. Kemudian klik simpan.

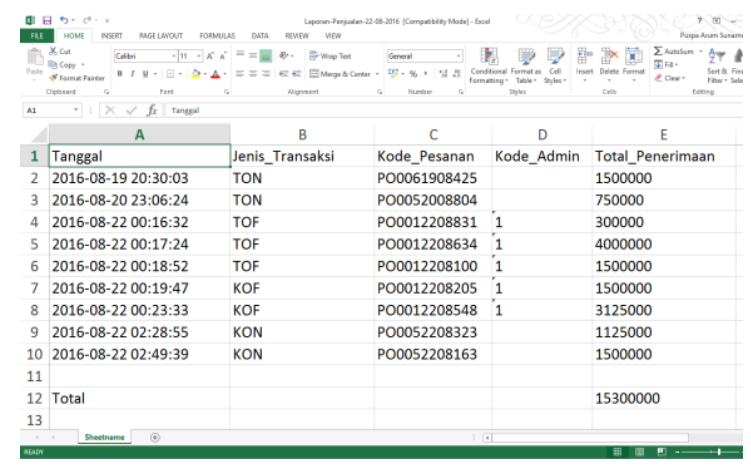

Gambar 29. Tampilan Laporan Penerimaan Kas Setelah Didownload

Tampilan diatas merupakan tampilan laporan penerimaan kas setelah didownload. Konten pada hasil download sama dengan laporan yang dilihat secara online. Laporan yang didownload akan disimpan dalam format Excel.

\section{d) Application Generation}

Tahap application generation dilakukan untuk merubah desain yang telah dibuat pada tahap process modelling kedalam bahasa pemrograman. Tahap ini menghasilkan program basis web yang siap dijalankan.

\section{e) Testing and Turnover}

Pada tahap ini pendesain sistem, programer, dan pemilik objek penelitian bekerjasama untuk mengevaluasi tingkat kesesuaian program yang telah dibuat dengan kebutuhan. Jika terjadi ketidaksesuaian atau ditemukan alternatif untuk mengoptimalkan sistem, maka akan langsung dilakukan turnover.

\section{Keterbatasan}

Keterbatasan dalam perancangan sistem informasi akuntansi penerimaan kas berbasis web pada Batik Pramanca adalah: (a) Rancangan sistem akuntansi penerimaan kas basis web ini hanya dapat diimplementasikan pada Batik Pramanca. (b) Tampilan interface yang menarik tidak terlalu diperhatikan. (c) Dibutuhkan ketelitian dalam penggunaan filter untuk menghasilkan akses laporan yang diinginkan.

\section{SIMPULAN DAN SARAN}

\section{Simpulan}

Berdasarkan penelitian yang telah dilakukan pada Batik Pramanca mengenai sistem informasi akuntansi penerimaan kas berbasis web dapat disimpulkan: Pertama, penerimaan kas pada Batik Pramanca berasal dari penjualan tunai, uang muka atas penjualan kredit, dan penerimaan piutang atas penjualan kredit yang dilakukan secara online maupun offline. Kedua dokumen yang digunakan dalam proses penerimaan kas Batik Pramanca adalah nota dan faktur. Sementara catatan yang digunakan adalah catatan penjualan, piutang, dan persediaan. Ketiga, fungsifungsi yang terkait dengan fungsi sistem penerimaan kas pada Batik Pramanca 


\section{JURNAL NOMINAL / VOLUME VI NOMOR 1 / TAHUN 2017}

antara lain fungsi penjualan, fungsi persediaan (gudang), dan fungsi pencatatan. Keempat, prosedur yang dilakukan dalam kegiatan penerimaan Batik Pramanca antara lain perosedur penjualan, prosedur penerimaan kas, prosedur persediaan (gudang), dan prosedur pencatatan. Kelima, informasi terkait dengan kegiatan penerimaan kas yang dibutuhkan oleh Batik Pramanca secara garis besar adalah laporan penjualan, laporan penerimaan kas, laporan piutang, dan laporan persediaan barang dagang. Keenam, alur sistem akuntansi penerimaan kas yang diterapkan pada Batik Pramanca bersifat manual. Sistem akuntansi berawal dari kegiatan penerimaan pesanan pada fungsi pembayaran, kemudian fungsi penerimaan kas akan menerima pembayaran atas pesanan tersebut. Setelah pembayaran dilakukan fungsi persediaan (gudang) akan menyerahkan barang pada pelanggan. Kemudian nota dan faktur akan di back up dalam fungsi pencatatan. Ketujuh, owner memegang tanggungjawab pada proses penciptaan informasi penerimaan kas. Dan seluruh hasil pengolahan data dalam sistem informasi akuntansi penerimaan kas akan digunakan sendiri oleh owner sebagai acuan dalam pengambilan keputusan. Kedelapan, Batik Pramanca belum menerapkan sistem pengendalian internal. Kesembilan, perancangan sistem informasi akuntansi penerimaan kas berbasis web yang sesuai dengan kebutuhan Batik Pramanca adalah rancangan sistem yang mampu menghasilkan output berupa informasi yang dibutuhkan dalam kegiatan operasional Batik Pramanca. (1) Tahap bussiness modelling pada Batik Pramanca memperoleh hasil data yang diperlukan dalam proses bisnis meliputi data pelanggan, data barang, dan data pesanan. Output yang diperlukan oleh pihak manajemen adalah laporan penjualan baik keseluruhan, tunai, kredit, online, maupun offline. Laporan penerimaan kas keseluruhan, online, maupun offline. Laporan piutang, laporan persediaan, history dan kartu pesanan. Pengguna informasi pada Batik Pramanca adalah Bapak Hasta Pramanca selaku owner sekaligus pengelola Batik Pramanca. Penanggungjawab atas proses penciptaan informasi tersebut adalah Bapak Hasta Pramanca dan istri selaku owner sekaligus pengelola Batik Pramanca. (2) Tahap data modelling pada Batik Pramanca memperoleh hasil tabel data pelanggan, administrator, barang, pesanan, detail pesanan, beban, pembayaran, dan detail pembayaran. (3) Tahap process modelling pada Batik Pramanca memperoleh hasil sebagai berikut: (a) Proses yang akan dilakukan dalam sistem informasi akuntansi penerimaan kas Batik Pramanca adalah proses mengelola data profil, 
mengelola data barang, mengelola data pesanan, mengelola data penjualan tunai, mengelola data penjualan kredit, dan membuat laporan penerimaan kas. (b) Dokumen yang dihasilkan adalah kartu pesanan, data customer, data admin, dan data barang. (c) Catatan yang dihasilkan antara lain laporan penerimaan kas, laporan penjualan, laporan persediaan, buku besar piutang, dan juga history. (4) Tahap application generation telah menghasilkan sistem informasi akuntansi penerimaan kas basis web terprogram yang siap untuk diujicoba. (5) Tahap testing and turnover yang bertujuan untuk menguji kesesuaian fungsi program dengan desain yang telah dibuat berlangsung dengan baik dan sesuai dengan estimasi waktu yang ditetapkan. Kesepuluh, keterbatasan dalam perancangan sistem informasi akuntansi penerimaan kas berbasis web pada Batik Pramanca adalah: (1) Rancangan sistem akuntansi penerimaan kas basis web ini hanya dapat diimplementasikan pada Batik Pramanca. (2) Rancangan ini belum dilengkapi kode unik pembayaran. (3) Tampilan interface yang menarik tidak terlalu diperhatikan.

Dibutuhkan ketelitian dalam penggunaan filter untuk menghasilkan akses laporan yang diinginkan.

\section{Saran}

Berdasarkan pada penelitian yang telah dilakukan, berikut saran yang dapat diberikan: Pertama, pemisahan fungsi yang jelas dan pengendalian intern yang tegas perlu ditingkatkan dikemudian hari. Kedua, Pengembangan sistem informasi akuntansi penerimaan kas basis web perlu dikembangkan sesuai dengan kebutuhan dan perkembangan teknologi agar dapat terus menunjang kegiatan bisnis yang dilakukan.

\section{DAFTAR PUSTAKA}

Anastasia Diana \& Lilis Setiawati. (2011). Sistem Informasi Akuntansi. Yogyakarta: Andi

Andri Kristanto. (2008). Perancangan Sistem Informasi dan aplikasinya. Yogyakarta: Gava Media

Bodnar, G. H., \& Hopwood, W. S. (2004). Accounting information systems. Upper Saddle River, N.J: Pearson Prentice Hall.

Edhy Sutanta. (2004). Sistem Basis Data. Yogyakarta : Graha Ilmu

Hall, James A. (2007) . Sistem Informasi Akuntansi, Edisi 4 Terjemahan. Jakarta:Salemba Empat

Hanif, Al Fatta. (2007). Analisis dan Perancangan Sistem Informasi. Yogyakarta: Andi

Indriyo Gitosudarmo dan Basri. (2002). Manajemen Keuangan. Yogyakarta:BPFE

Jogiyanto. (2000). Sistem Informasi Berbasis Komputer. Yogyakarta : BPFE (2005). Sistem Teknologi Informasi. Yogyakarta: Andi 
Kendall, J.E. \& Kendall, K.E. 2010. Analisis dan Perancangan Sistem. Jakarta: Indeks.

Lia Setiawan. (2009). Pembuatan Website E-Commerce Butik Diar Lutfi Surakarta. Tugas Akhir Diploma. MIPA UNS

Limulbin, Novia.(2011).Perancangan Sistem Penjualan Tunai Berbasis Web sebagai Media Informasi Produk bagi Konsumen pada PT. Karya Swadipta Pratama Bekasi. UNY:Skripsi

M. Rudyanto Arief. (2011). Pemrograman Web Dinamis menggunakan PHP dan MySQL. Yogyakarta: Andi

Marakas, G.M. 2006. Sistem Analysis Design: an Active Approach. New York: Mc.Graw-Hill.

Mc.,Leod, R. Jr. 2002. Sistem Development: A Project Management Approach. New York: Leigh Publishing LLC.

Mulyadi. (2001). Sistem Akuntansi. Jakarta: Salemba Empat

Mustakini, Jogiyanto Hartono. Sistem Informasi Teknologi, Yogyakarta:Andi Offset.2009

Naufal, Muhammad Ibnu.(2011).Sistem Informasi Akuntansi Penerimaan Kas Pada BMT Bintaro.UIN Syarif Hidayatullah:Skripsi

Nugroho, Widjajanto. (2001). Sistem Informasi Akuntansi. Jakarta : Erlangga

Nur Indriantoro \& Bambang Supomo. (2009). Metode Penelitian Bisnis untuk Akuntansi \& Manajemen. Yogyakarta: BPFE.

Nurhayati, Noviana.(2013).Perancangan Sistem Informasi Akuntansi
Penjualan Tunan Berbasis Web

Pada Toko Bariklana. UNY:Skripsi

Pirnawati, Eni.(2013). Sistem Akuntansi Penerimaan Kas Dari Piutang Pada Koperasi Serba Usaha (KSU) Makmur Abadi Kecamatan Kayen Kabupaten Pati. UNNES:Skripsi

Pressman, R.S. 2012. Rekayasa Perangkat Lunak: Pendekatan Praktisi. Yogyakarta: Penerbit Andi.

SourceForge.net: Project Statistics for Notepad++. SourceForge.Net. Diakses tanggal 2015-09-25.

Sunargo, Astrid.(2009).Analisis Dan Perancangan Sistem Informasi Akuntansi Penerimaan Dan Pengeluaran Kas Berbasis Web Untuk Menghasilkan Laporan Keuangan Partai Politik.BINUS:Skripsi

Top Downloads - For all time, updated daily. SourceForge. Diakses tanggal 2015-09-25.

Whitten, J.L. \& Bentley, L.D. 2004. Sistem Analysis \& Design Methods: Sixth Edition. New York: Mc.Graw-Hill. 